\title{
Treatment of wastewater from raw rubber processing industry using water lettuce macrophyte pond and the reuse of its effluent as biofertilizer
}

\author{
H.I. Owamah ${ }^{\mathrm{a}, *}$, M.A. Enaboifo ${ }^{\mathrm{b}}$, O.C. Izinyon $^{\mathrm{c}}$ \\ a Department of Civil Engineering, College of Science and Engineering, Landmark University, P.M.B. 1001, Omu-Aran, Kwara State, Nigeria \\ ${ }^{\mathrm{b}}$ Department of Crop Science, University of Benin, Edo State, Nigeria \\ ${ }^{\mathrm{c}}$ Department of Civil Engineering, University of Benin, Edo State, Nigeria
}

\section{A R T I C L E I N F O}

\section{Article history:}

Received 7 January 2014

Accepted 19 August 2014

Available online 17 September 2014

\section{Keywords:}

Wastewater

Water lettuce

Macrophyte pond

Biofertilizer

Maize plant

\begin{abstract}
A B S T R A C T
A 3-year detailed investigation on the use of water lettuce macrophyte pond for the purification of wastewater from rubber processing industries and the reuse of the final effluent as biofertilizer is presented. Baseline wastewater quality information was collected on a monthly basis and analysed for one year before the introduction of water lettuce to $50 \%$ pond surface cover. This was done to reliably determine the parameters that exceeded limits and need treatment. These parameters are: phosphate, nitrates, $\mathrm{pH}$, biological oxygen demand, conductivity, turbidity, total dissolved solid and total suspended solid. The effluents from the macrophyte ponds were then monitored mainly on monthly basis for chemical, physical and biological parameters. The treatment and analyses of parameters with exceedance were carried out in the ponds, using the retention periods of 2 weeks, 4 weeks, 8 weeks and 12 weeks for 1 st, 2 nd and 3rd inoculations. The result of the study showed a progressive reduction in the level of wastewater contaminants fed into the macrophyte pond. Significant reductions within permissible limits were obtained for most of the parameters except TSS and turbidity. Final effluent from the ponds was also found to boast the height, stem girth, leaf area and biomass yield of maize plant. Maximum plant height of $117.5 \pm 7.6 \mathrm{~cm}$ was obtained using treatment 2 at 63 day after planting. The weight of cob produced from treatment 2 is $46.2 \pm 6.1 \mathrm{~g}$ while the weight of cob produced by the control experiment is $21.3 \pm 6.7 \mathrm{~g}$. The chemical composition of the resulting water lettuce biomass shows it could be utilized as forage for feeding animals.
\end{abstract}

(c) 2014 Elsevier B.V. All rights reserved.

\section{Introduction}

Macropytes are known to grow rapidly in wastewater due to the presence of necessary growth requirements (Papadopoulos et al., 2011). They utilize the nutrients in wastewater for growth and other metabolic activities. Water scarcity is usually caused by insufficient local water resources and reduced water quality due to increasing pollution (Jiang, 2009). The release of untreated wastewater into water bodies and land contributes much to this water pollution. It has been estimated that over $40 \%$ of the population of the world (representing about 80 countries), are already experiencing water stress, with about 30 of these countries suffering water scarcity in most parts of the year (Kivaisi, 2001).

\footnotetext{
* Corresponding author. Tel.: +234 8035705814 .

E-mail addresses: dahilla222@yahoo.com,owamah.hilary@lmu.edu.ng (H.I. Owamah).
}

In addition to this natural scarcity of freshwater, the quality of the available freshwater in many developing countries is equally deteriorating as a result of pollution (Kivaisi, 2001). Contaminated drinking water and poor sanitation were reported to rank third in the list of the 20 leading health risk factors in developing nations (Owamah et al., 2013). Furthermore, inadequate energy supply and pollution have been reported as major challenges in Nigeria (Owamah et al., 2014a,b; Dahunsi et al., 2014).

Wastewater pollution from rubber processing industries has been on the increase in Africa and Asia as a result of the increasing number of rubber producing factories due to the presence of virgin forests with large number of mature rubber trees. Rubber producing factories are one of the agro-industries that produce large quantities of wastewater. The practice of indiscriminate discharge of large volumes of wastewater from processing factories to soil and watercourses poses lot of danger to the environment and man. In Nigeria most of the rubber industries discharge their wastes into rivers/streams because they are rarely equipped with 
adequate treatment facilities due to the high cost of conventional treatment technologies. The negative impact of wastewater on the environment calls for the need to develop alternative and economical methods of treatment/utilization. Wastewater reuse is also an important strategy for conserving water resources, particularly in areas suffering from water shortage (Kivaisi, 2001). Constructed wetlands have been reported as cheap technologies and can treat various forms of wastewater of varying strength. They do not need complicated maintenance like other conventional wastewater treatment technologies such as activated sludge system (Stefanakis et al., 2011; Uysal, 2013; Li et al., 2013).

An efficient removal of faecal bacteria from septage in full-scale duckweed-covered pond system was reported by Papadopoulos et al. (2011). Duckweed was equally reported to be efficient for chromium removal from wastewater (Uysal, 2013). Li et al. (2013) reported that the ability of wetland plants to take up nitrogen and phosphorous directly was not affected by the strength of sewage and that total accumulation was governed by the biomass of whole plants. Recent studies have also shown interest in the appropriate selection of macrophyte species for wetlands/stabilization ponds (Li et al., 2013; Brisson and Chazarenc, 2009).

Adsorption through agricultural products such as rice husk, sugarcane bagasse, activated cassava peels, coconut shell, etc. has been extensively studied and found useful and more economical than the conventional treatment system for the removal of toxic metals such as dyes/colour, chromium (Cr), mercury (Hq), copper(Cu), etc. from aqueous solution (Owamah, 2014). Also, the use of microorganisms such as algae, fungi and bacteria for contaminants removal from wastewater has been extensively reported in literature.

Apart from a few reports; Wu (1995), Snow and Ghaly (2008), etc. in literature, information on the use of water lettuce waste stabilization pond for industrial wastewater treatment and the reuse of the resulting effluent as biofertilizer is still scanty. This study was therefore carried out to assess the efficiency of water lettuce based pond for the treatment of wastewater from rubber processing factories. The reuse of the treated effluent as liquid biofertilizer was also investigated. Water lettuce (Pistia stratiotes Linn) belongs to the family Araceae. A free-floating aquatic herb with thick, succulent leaves, profuse under water stolons and long, white, unbranched fibrous roots that may sometimes attach to the bottom of shallow waters. It reproduces mainly vegetatively by buds and stolons and rarely produces seeds. They are oblong in shape, $6-12 \mathrm{~cm}$ long and $5 \mathrm{~cm}$ broad, spongy, strongly inflated and softly hairy on both surfaces, the lower surface has conspicuous veins (nerves) radiating from the base of the leaves. It is a common aquatic weed that occurs in still waters, ponds and pools or in slow flowing rivers and streams throughout West Africa. Aquatic weeds growing in ponds and lakes are beneficial for fish and wildlife. Besides providing food and dissolved oxygen, aquatic weeds can also trap excessive nutrients and detoxify chemicals (Masters, 1991).

\section{Methodology}

\subsection{Sources of effluent, sample collection and analysis}

Two rubber factories/sites (Factories A and B) were chosen for this study. The factories were situated along the Ikpoba River which runs across the Eastern end of Benin City, South-South, Nigeria. The entire experiment (baseline wastewater quality monitoring, treatment in the macrophyte pond, and utilization of resulting effluent for growing maize plants) began in November 2003 and ended in March, 2006. The efficiency of water lettuce based macrophyte pond to treat wastewater from rubber processing industries was monitored for three months for each inoculation by varying the retention time. In order to obtain reliable physicochemical and biological parameters of wastewater from the factories prior to treatment in the macrophyte pond, baseline wastewater quality monitoring was performed for one year, starting from November 01, 2003 to November 01, 2004.

\subsection{Establishment of water lettuce based pond systems}

A batch system of storage ponds was established to compare with a real field macrophyte pond. The ponds were established in plastic pots in the Screen House at the Department of Crop Science, University of Benin, Nigeria. Wastewater quality monitoring was carried out on these pots in order to determine the effectives of a water lettuce based pond for treatment of rubber processing wastewater.

\section{Data collection}

\subsection{Effluent sampling}

Effluent samples were collected from November 25, 2004 to September 25, 2005 from the water lettuce based macrophyte ponds. New high-density (polyethylene terephthalate, PET) screwcapped containers of $1.5 \mathrm{~L}$ capacity were used to collect the effluent samples. The PET containers and stoppers were thoroughly washed with distilled water for three times before collecting the actual sample. The bottles were immediately stoppered, labelled, icecooled and taken to Edo State Environmental Laboratory, Benin, and the Chemistry Department Laboratory of Federal Polytechnic, AdoEkiti, all in Nigeria. As was described by Dahunsi et al., 2014 and Owamah et al. (2013), at each site one bottle was filled with effluent having no acid while the other bottle was filled with the effluent from the same point and acidified by adding a few drops of $5 \% \mathrm{HNO}_{3}$ to stop the activities of microorganisms. At the same time, samples for microbial analysis were collected using autoclave-sterilized sample bottles from the same locations. The non-acidified samples and samples for microbial analysis were transported to Edo State Environmental Laboratory, Benin for the analysis of physical parameters, anions and total coliform bacteria while the acidified samples were transported to the Chemistry Department Laboratory of Federal Polytechnic, Ado-Ekiti, for metals analysis. The effluent samples were preserved in a refrigerator at $4{ }^{\circ} \mathrm{C}$ to keep the water content intact until analyses were carried out (Owamah et al., 2014a,b; Dahunsi et al., 2014).

\subsection{Analytical procedures}

The parameters of $\mathrm{pH}$ (HI 9024-C, Hanna Instruments, Smithfield, RI, USA), temperature (HI 98517, Hanna Instr.), salinity (HI 19311, Hanna Instr.), electrical conductivity (HI 2315, Hanna Instr.), and total dissolved solids (TDS)(VSI 22, VSI Electronics Private Limited, Punjab, India) were analysed in-situ using the mentioned hand digital meters. Dissolved oxygen of the water samples were analysed using the azide modification of Winkler's method (Owamah et al., 2014a,b). As described in APHA (1992, 2012), chloride was determined by titration. Ultraviolet spectrophotometer screening method was used in the determination of the major anions by strictly following the method described in APHA (1992) using a UV spectrophotometer (DR 2800, HACH, Washington, USA). In order to ensure that the analyses were reliable and reproducible, blank, standard and pre-analysed samples were analysed after every 10 samples (Owamah et al., 2013). Standard methods were used to count the total coli form bacteria as maximum probability number (MPN) in water samples (Owamah et al., 2014a,b). Metals were analysed with atomic absorption spectrophotometer (AAS) (Sens AA 3000, GBC, Australia) following the method in APHA (2012). 


\subsection{Treatment}

In the first year of the study and before the introduction of aquatic weeds into the ponds, the wastewater biological and physicochemical parameters were analysed on monthly basis for one year using standard methods (APHA, 2012). Parameters analysed include $\mathrm{pH}$, turbidity, electrical conductivity (EC), temperature, total suspended solids (TSS), total dissolved solids (TDS), dissolved oxygen (DO), hardness, biological oxygen demand (BOD), chemical oxygen demand (COD), phosphates, nitrates, iron, total coliform, Escherichia coli counts, etc. This was done to reliably determine the parameters that were usually above the permissible limits of the WHO for disposal into water bodies. These parameters with exceedance were then utilized as benchmark for subsequent wastewater quality monitoring (composite samples) and treatment in the macrophyte ponds. Only composite wastewater samples were fed into the macrophyte ponds for treatment (Table 2 ).

After the introduction of the aquatic weeds, effluent samples from the ponds were collected on a 2-week and later on monthly basis from November 25, 2004 through September 25, 2005 for analyses of physicochemical and biological parameters in order to determine the degree of treatment offered by the water lettuce based pond. Three sample crops termed 1st, 2nd and 3rd inoculations were utilized for this study. Treatments by $1 \mathrm{st}$, 2nd and 3rd inoculations occurred from November 25, 2014 to February 25, 2005, March 25 to June 25, and July 25 to September 25, 2005 respectively.

\subsection{Evaluation of the biofertilizer quality of final effluent}

In order to assess the biofertilizer quality of the resulting effluent, the effluent was applied at intervals of 2 weeks starting from 2 weeks prior to planting through 8 weeks after planting to a small maize farm cultivated for this research. A $10 \mathrm{~m} \times 10 \mathrm{~m}$ plot (of predominantly loamy soil) was partitioned into eight smaller plots of $1 \mathrm{~m} \times 1 \mathrm{~m}$ for the eight different treatments. Two seeds of maize were planted in just one hole in each plot (Iken and Amusa, 2004). A Nigerian late maturity Maize variety (TZESR-20) was used for this study. Maize seeds were tested for viability before planting in order not to utilize unhealthy seeds for the experiment. Effluent used as biofertilizer for growing the maize plants was a mixture of the effluents from the 12 week retention period of 1 st, 2 nd and 3 rd inoculations. The eight different treatment regimes are:

a. Treatment (Trt) 1: application of effluent 2 weeks before planting.

b. Treatment (Trt) 2: application of effluent at time of planting.

c. Treatment (Trt) 3: application of effluent 2 weeks after planting.

d. Treatment (Trt) 4: application of effluent 4 weeks after planting.

e. Treatment (Trt) 5: application of effluent 6 weeks after planting.

f. Treatment (Trt) 6: application of effluent 8 weeks after planting.

g. Treatment (Trt) 7: application of effluent 10 weeks after planting.

h. Treatment (Trt) 8: control/no application of effluent.

Apart from the control plot, all plots were treated with only $1 \mathrm{~L}$ of the effluent biofertilizer. The maize plants were allowed to grow under the specified treatment conditions for four months (November 01, 2005-March 01, 2006). Thereafter, roots, stems and leaves were collected. This was done to assess the effect of effluent application and time of application on the growth parameters of the maize plant. Data were taken during this period on the following parameters: plant height, stem girth, leaf number, leaf area and biomass yield. The chemical analyses of the nutrient and water composition of the water lettuce plants after wastewater treatment were performed using the methods outlined in Fonkou et al. (2002).
Table 1

Mean microbial profile of effluent at different inoculation periods.

\begin{tabular}{llll}
\hline $\begin{array}{c}\text { Inoculating } \\
\text { time }\end{array}$ & $\begin{array}{l}\text { Coliform count, } \\
\text { CFU } 100 \mathrm{~mL}^{-1}\end{array}$ & $\begin{array}{l}\text { Total aerobic } \\
\text { plate count } \\
\text { (TAPC) } \\
\text { CFU mL }\end{array}$ & Pathogens \\
\hline 2 weeks & $14.0 \pm 2.1$ & $2.4 \pm 0.1$ & $\begin{array}{l}\text { Diplococcispp } \\
\text { Thermophilus }\end{array}$ \\
4 weeks & $10.0 \pm 1.8$ & $2.0 \pm 0.3$ & $\begin{array}{l}\text { influenza } \\
\text { Tetracoccispp }\end{array}$ \\
8 weeks & $22.0 \pm 2.6$ & $4.0 \pm 0.1$ & E. coli, Bacillus spp \\
\hline
\end{tabular}

Results are expressed as mean \pm standard deviation of triplicate values of the same sample.

This was done to evaluate the possibility of utilizing the resulting water lettuce biomass as forage for feeding animals.

\subsection{Statistical analyses}

Microsoft Office Excel 2007 software package was used to statistically analyze data with a significance level of $P<0.05$ using the Analysis of Variance (ANOVA). The mean values of the parameters analysed were computed. The standard deviation and range of the values were also calculated to indicate the extent of deviation in the values of the parameters across the months of sampling.

\section{Results}

The microbial profile of the rubber processing wastewater (composite) used in this study is shown in Table 1. The highest coliform count and total aerobic plate count (TAPC) as obtained in the 8 th week of the experiment were $22 \pm 2.6 \mathrm{CFU} 100 \mathrm{~mL}^{-1}$ and $4.0 \pm 0.1 \mathrm{CFU} \mathrm{mL}^{-1}$ respectively while the lowest coliform count and TAPC of $5 \pm 0.1 \mathrm{CFU} 100 \mathrm{~m} \mathrm{~L}^{-1}$ and $1.2 \pm 0.11 \mathrm{CFU} \mathrm{mL}^{-1}$ respectively, were obtained in the 12th week. Microorganisms isolated from the effluent include Diplococci, Tetracocci and Bacillus species, Thermophilus influenza and E. coli (Table 1). Table 2 shows the result of the physicochemical analysis of the effluent from Factories A, B, and composite samples of both factories. For the two factories, the values obtained for DO, total coliform, E. coli count, nitrates, $\mathrm{pH}$, temperature, total hardness and TDS were within the permissible limits of the World Health Organization (WHO) and the Nigerian Federal Ministry of Environment (FME) while values for BOD, TSS and $\mathrm{PO}_{4}$ were above the maximum allowable limits for effluent discharge into water bodies and land as stipulated by the WHO and FME. From the analyses of the composite samples utilized as influent to the macrophyte pond, the efficiency of the weekly treatment with water lettuce is shown in Table 3. The highest DO improvement (151.6\%) and BOD removal (90.6\%) were obtained in the 12 th week of the experiment. Reduction in TSS reached its peak during the 4 th week with $98.8 \%$ efficiency. Also, maximum total coliform reduction occurred in the 12 th week with a removal efficiency of $97.93 \%$. Reduction in $\mathrm{NO}_{3}$ was most efficient during the 4 th week with $95 \%$ efficiency while $\mathrm{PO}_{4}$ reduction peaked during the 8th week with $99.3 \%$ efficiency. Maximum COD and $\mathrm{Na}$ reductions were achieved during the 12 th week with $85.5 \%$ and 99.4\% efficiencies respectively. Table 4 shows the effect of treated rubber effluent on the height of maize (Zea mays). At 42 'Days After Planting' (DAP), the highest plant height of $21.5 \pm 2.2 \mathrm{~cm}$ was obtained with treatment 2 while the lowest height of $17.9 \pm 3.2 \mathrm{~cm}$ was obtained with treatment 7. At 49 DAP; maximum height of $29.7 \pm 2.4 \mathrm{~cm}$ was obtained with treatment 2 while the minimum height of $24.7 \pm 1.7 \mathrm{~cm}$ was obtained with treatment 6 . At 56 DAP; maximum height of $57.1 \pm 4.8 \mathrm{~cm}$ was obtained with treatments 2 and 5 while the minimum $(44.8 \pm 3.4 \mathrm{~cm})$ was obtained with treatment 1. At $63 \mathrm{DAP}$; the maximum plant height of $117.5 \pm 7.6 \mathrm{~cm}$ 
Table 2

Mean physico-chemical characteristics of raw rubber processing wastewater from Factories A, and B.

\begin{tabular}{|c|c|c|c|c|c|c|c|c|}
\hline \multirow{2}{*}{$\begin{array}{l}\text { Parameters } \\
(\mathrm{mg} / \mathrm{L})\end{array}$} & \multicolumn{3}{|l|}{ Factory A } & \multicolumn{5}{|l|}{ Factory B } \\
\hline & 1 st four months & 2nd four months & 3rd four months & 1 st four months & 2nd four months & 3rd four months & WHO & FEM \\
\hline DO & $1.5 \pm 0.1$ & $1.5 \pm 0.1$ & $1.6 \pm 0.2$ & $1.6 \pm 0.1$ & $1.50 \pm 0.0$ & $1.7 \pm 0.2$ & & 1200 \\
\hline $\mathrm{BOD}_{5}$ & $203.0 \pm 20.3$ & $208.0 \pm 20.2$ & $205.8 \pm 19.6$ & $200.0 \pm 20.5$ & $207.4 \pm 18.7$ & $205.6 \pm 10.2$ & & 50.00 \\
\hline TSS & $860.1 \pm 50.5$ & $851.0 \pm 40.6$ & $856.0 \pm 42.2$ & $854.0 \pm 35.7$ & $849.0 \pm 20.6$ & $851.0 \pm 40.7$ & & 30 \\
\hline "Total coliform and E. coli & $239.0 \pm 15.6$ & $242.7 \pm 14.3$ & $241.0 \pm 14.7$ & $241.0 \pm 10.8$ & $242.6 \pm 25.6$ & $241.5 \pm 22.6$ & & 400 \\
\hline $\mathrm{NH}_{3}$ & $1.3 \pm 0.1$ & $1.3 \pm 0.1$ & $1.3 \pm 0.1$ & $1.3 \pm 0.1$ & $1.3 \pm 0.1$ & $1.2 \pm 0.1$ & & \\
\hline Nitrates & $1.1 \pm 0.1$ & $1.1 \pm 0.1$ & $1.2 \pm 0.1$ & $1.0 \pm 0.1$ & $1.1 \pm 0.1$ & $1.1 \pm 0.1$ & 50 & 20 \\
\hline $\mathrm{PO}_{4}$ & $59.0 \pm 5.4$ & $60.1 \pm 4.2$ & $60.1 \pm 7.1$ & $55.6 \pm 5.2$ & $59.9 \pm 6.2$ & $60.1 \pm 7.3$ & & 5 \\
\hline Colour & $70.1 \pm 10.4$ & $69.84 \pm 9.3$ & $70.2 \pm 11.4$ & $69.1 \pm 11.4$ & $69.79 \pm 7.3$ & $70.3 \pm 8.6$ & & \\
\hline${ }^{* *} \mathrm{pH}$ & $8.0 \pm 0.1$ & $8.1 \pm 0.1$ & $8.1 \pm 0.1$ & $8.0 \pm 0.1$ & $8.1 \pm 0.1$ & $8.1 \pm 0.1$ & $6.5-9$ & $6-9$ \\
\hline $\mathrm{EC}$ & $859.6 \pm 60.3$ & $861.4 \pm 64.1$ & $860.5 \pm 45.9$ & $860.9 \pm 43.3$ & $862.1 \pm 51.7$ & $859.7 \pm 56.8$ & & \\
\hline${ }^{* * *}$ Temperature & $33.0 \pm 0.2$ & $32.9 \pm 0.2$ & $33.0 \pm 0.2$ & $32.7 \pm 0.2$ & $32.9 \pm 0.2$ & $32.8 \pm 0.2$ & 85 & 40 \\
\hline Turbidity & $175.7 \pm 10.3$ & $174.9 \pm 8.9$ & $175.1 \pm 8.5$ & $175.8 \pm 11.2$ & $176.0 \pm 10.7$ & $175.1 \pm 9.6$ & & \\
\hline COD & $74.5 \pm 5.7$ & $74.3 \pm 4.8$ & $74.0 \pm 4.8$ & $73.9 \pm 5.3$ & $74.19 \pm 7.5$ & $73.9 \pm 6.2$ & & \\
\hline Sodium & $1.7 \pm 0.1$ & $1.6 \pm 0.1$ & $1.5 \pm 0.1$ & $1.6 \pm 0.1$ & $1.6 \pm 0.1$ & $1.5 \pm 0.1$ & & \\
\hline Potassium & $3.0 \pm 0.2$ & $2.1 \pm 0.1$ & $2.1 \pm 0.1$ & $3.1 \pm 0.1$ & $2.3 \pm 0.1$ & $2.1 \pm 0.1$ & & \\
\hline Total hardness & $298.3 \pm 18.5$ & $300.2 \pm 24.7$ & $300.2 \pm 25.8$ & $299.3 \pm 27.7$ & $301.1 \pm 19.6$ & $300.9 \pm 19.7$ & 500 & \\
\hline TDS & $606.5 \pm 20.2$ & $606.1 \pm 23.5$ & $607.0 \pm 19.5$ & $605.7 \pm 15.4$ & $606.0 \pm 19.3$ & $607.0 \pm 24.3$ & & 2000 \\
\hline TSS & $146.1 \pm 12.2$ & $145.0 \pm 10.3$ & $146.3 \pm 9.6$ & $147.0 \pm 7.7$ & $145.3 \pm 6.4$ & $146.0 \pm 10.3$ & & \\
\hline
\end{tabular}

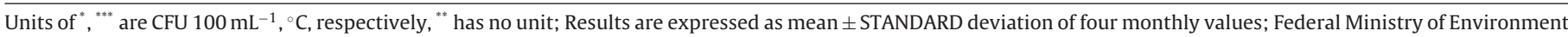
(Nigeria).

Table 3

Mean efficiency of water lettuce in treatment of rubber processing effluent.

\begin{tabular}{|c|c|c|c|c|c|c|c|c|c|}
\hline \multirow[t]{2}{*}{ Parameters(mg/L) } & \multicolumn{3}{|c|}{2 weeks treatment } & \multicolumn{2}{|c|}{4 weeks treatment } & \multicolumn{2}{|c|}{8 weeks treatment } & \multicolumn{2}{|c|}{12 weeks treatment } \\
\hline & CW (influent) & AT (effluent) & \% Efficiency & AT (effluent) & \% Efficiency & AT (effluent) & \% Efficiency & AT (effluent) & \% Efficiency \\
\hline DO & $1.6 \pm 0.1$ & $3.5 \pm 0.1$ & 122.6 & $3.9 \pm 0.1$ & 149 & $3.9 \pm 0.2$ & 150.3 & $3.9 \pm 0.1$ & 151.6 \\
\hline $\mathrm{BOD}_{5}$ & $206 \pm 5.8$ & $156 \pm 10.9$ & 24.3 & $105 \pm 10.3$ & 49 & $43.6 \pm 4.6$ & 78.9 & $19.5 \pm 3.2$ & 90.6 \\
\hline TSS & $852 \pm 20.3$ & $455 \pm 6.7$ & 46.6 & $10.5 \pm 1.8$ & 98.8 & $600 \pm 50.5$ & 29.6 & $402 \pm 11.1$ & 52.8 \\
\hline${ }^{*}$ Total coliforms & $242 \pm 7.4$ & $158 \pm 6.9$ & 34.7 & $110 \pm 8.9$ & 58.7 & $8.3 \pm 2.3$ & $96.6 \pm 7.4$ & $5.0 \pm 0.2$ & 97.9 \\
\hline $\mathrm{NO}_{3}$ & $1.0 \pm 0.1$ & $1.5 \pm 0.2$ & 45 & $0.1 \pm 0.0$ & 95 & $10.5 \pm 4.4$ & 95.0 & $9.8 \pm 2.5$ & 88.2 \\
\hline $\mathrm{PO}_{4}$ & $60 \pm 4.6$ & $40 \pm 10.2$ & 33.3 & $0.1 \pm 0.0$ & 99.9 & $0.4 \pm 0.1$ & 99.3 & $1.0 \pm 0.1$ & 98.3 \\
\hline COD & $74.5 \pm 4.8$ & $66 \pm 8.5$ & 11.4 & $42 \pm 3.5$ & 43.6 & $15.5 \pm 2.6$ & 79.2 & $10.8 \pm 0.5$ & 85.5 \\
\hline Sodium & $1.6 \pm 0.2$ & $1.6 \pm 0.1$ & - & $1.05 \pm 0.1$ & 32.3 & $0.01 \pm 0.0$ & 99.4 & $0.01 \pm 0.0$ & 99.4 \\
\hline${ }^{* *} \mathrm{pH}$ & $8.5 \pm 0.2$ & $8.4 \pm 0.2$ & - & $7.8 \pm 0.2$ & - & $5.6 \pm 0.1$ & - & $5.8 \pm 0.1$ & \\
\hline
\end{tabular}

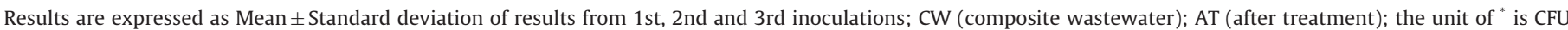
$100 \mathrm{~m} \mathrm{~L}^{-1}$; ${ }^{* *}$ has no unit.

Table 4

Effect of treated rubber effluent on the plant height $(\mathrm{cm})$ and leaf number of maize (Z. mays).

\begin{tabular}{|c|c|c|c|c|c|}
\hline \multirow{2}{*}{ Treatments } & \multicolumn{5}{|c|}{ (a) Plant height $(\mathrm{cm})$} \\
\hline & \multicolumn{5}{|c|}{ Time of application } \\
\hline & 42 DAP & 49 DAP & 56 DAP & 63 DAP & 70 DAP \\
\hline Trt 1 & $19.9 \pm 2.3$ & $28.2 \pm 2.5$ & $44.8 \pm 3.4$ & $72.1^{\mathrm{b}} \pm 5.2$ & $110.8 \pm 8.6$ \\
\hline Trt 2 & $21.5 \pm 2.2$ & $29.7 \pm 2.4$ & $57.1 \pm 4.8$ & $117.5^{\mathrm{a}} \pm 7.6$ & $134.0 \pm 9.2$ \\
\hline Trt 3 & $19.4 \pm 1.7$ & $25.3 \pm 2.3$ & $48.3 \pm 6.6$ & $94.9^{\mathrm{ab}} \pm 7.9$ & $123.3 \pm 10.2$ \\
\hline Trt 4 & $20.7 \pm 2.8$ & $27.1 \pm 2.7$ & $55.6 \pm 5.1$ & $115.9^{\mathrm{a}} \pm 10.3$ & $127.1 \pm 7.5$ \\
\hline Trt 5 & $19.0 \pm 1.9$ & $25.7 \pm 3.1$ & $57.1 \pm 4.9$ & $106.4^{a} \pm 8.6$ & $131.3 \pm 10.4$ \\
\hline Trt 6 & $18.7 \pm 2.3$ & $24.7 \pm 2.2$ & $52.3 \pm 4.6$ & $111.6^{\mathrm{a}} \pm 15.1$ & $122.0 \pm 9.4$ \\
\hline Trt 7 & $17.9 \pm 3.2$ & $24.7 \pm 1.7$ & $47.3 \pm 5.5$ & $103.5^{\mathrm{a}} \pm 8.3$ & $124.1 \pm 12.5$ \\
\hline \multirow[t]{2}{*}{ Trt 8} & $18.5 \pm 1.7$ & $25.6 \pm 2.6$ & $53.6 \pm 7.3$ & $94.5^{\mathrm{ab}} \pm 13.3$ & $122.3 \pm 15.8$ \\
\hline & \multicolumn{5}{|c|}{ (b) Number of leaves } \\
\hline \multirow[t]{2}{*}{ Treatments } & \multicolumn{5}{|c|}{ Time of application } \\
\hline & $42 \mathrm{DAP}$ & 49 DAP & 56 DAP & 63 DAP & $70 \mathrm{DAP}$ \\
\hline Trt 1 & 5 & 5 & 7 & 8 & 8 \\
\hline Trt 2 & 6 & 7 & 8 & 8 & 9 \\
\hline Trt 3 & 5 & 6 & 8 & 9 & 9 \\
\hline Trt 4 & 6 & 6 & 8 & 9 & 9 \\
\hline Trt 5 & 5 & 7 & 8 & 9 & 9 \\
\hline Trt 6 & 5 & 7 & 8 & 9 & 9 \\
\hline Trt 7 & 5 & 6 & 7 & 9 & 9 \\
\hline Trt 8 & 5 & 6 & 8 & 9 & 8 \\
\hline
\end{tabular}

*Results are expressed as mean \pm standard deviation of duplicate values of two different samples.

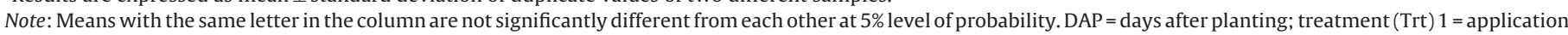

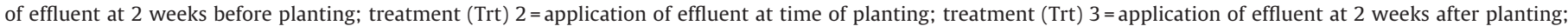

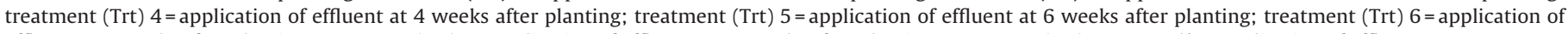
effluent at 8 weeks after planting; treatment (Trt) $7=$ application of effluent at 10 weeks after planting; treatment (Trt) $8=$ control/no application of effluent. 
Table 5

Effect of treated rubber effluent on the stem girth $(\mathrm{cm})$ and leaf area $\left(\mathrm{cm}^{2}\right)$ of maize (Z. mays).

(a) Stem girth $(\mathrm{cm})$

\begin{tabular}{|c|c|c|c|c|c|}
\hline \multirow[t]{2}{*}{ Treatments } & \multicolumn{5}{|l|}{ Time of application } \\
\hline & $42 \mathrm{DAP}$ & 49 DAP & 56 DAP & 63 DAP & 70 DAP \\
\hline Trt 1 & $4.0^{\mathrm{ab}} \pm 0.1$ & $4.7^{\mathrm{ab}} \pm 0.4$ & $4.5^{\mathrm{ab}} \pm 0.4$ & $4.5 \pm 0.1$ & $4.4^{\mathrm{ab}} \pm 0.3$ \\
\hline Trt 2 & $4.1^{\mathrm{a}} \pm 0.3$ & $4.9^{a} \pm 0.3$ & $4.7^{\mathrm{a}} \pm 0.1$ & $4.5 \pm 0.6$ & $4.6^{\mathrm{a}} \pm 0.1$ \\
\hline Trt 3 & $3.6^{\mathrm{ab}} \pm 0.1$ & $4.4^{\mathrm{b}} \pm 0.2$ & $4.4^{\mathrm{ab}} \pm 0.1$ & $4.4 \pm 0.4$ & $4.5^{\mathrm{ab}} \pm 0.6$ \\
\hline Trt 4 & $4.1^{\mathrm{a}} \pm 0.4$ & $4.7^{\mathrm{ab}} \pm 1.0$ & $4.5^{\mathrm{ab}} \pm 0.8$ & $4.5 \pm 0.7$ & $4.3^{\mathrm{ab}} \pm 0.1$ \\
\hline Trt 5 & $3.7^{\mathrm{ab}} \pm 0.1$ & $4.4^{\mathrm{b}} \pm 0.3$ & $4.5^{\mathrm{ab}} \pm 0.4$ & $4.5 \pm 0.2$ & $4.3^{\mathrm{ab}} \pm 0.1$ \\
\hline Trt 6 & $4.0^{\mathrm{ab}} \pm 0.2$ & $4.7^{\mathrm{ab}} \pm 0.4$ & $4.4^{\mathrm{ab}} \pm 0.6$ & $4.2 \pm 0.7$ & $4.1^{\mathrm{ab}} \pm 0.2$ \\
\hline Trt 7 & $3.8^{\mathrm{ab}} \pm 0.1$ & $4.4^{\mathrm{b}} \pm 0.3$ & $4.4^{\mathrm{ab}} \pm 0.5$ & $4.3 \pm 0.2$ & $4.6^{\mathrm{a}} \pm 0.8$ \\
\hline Trt 8 & $3.4^{\mathrm{b}} \pm 0.2$ & $4.4^{\mathrm{b}} \pm 0.5$ & $4.0^{\mathrm{b}} \pm 0.5$ & $3.9 \pm 0.1$ & $3.9^{\mathrm{b}} \pm 0.2$ \\
\hline
\end{tabular}

b. Leaf area

\begin{tabular}{ll}
\hline Treatments & Leaf area $\left(\mathrm{cm}^{2}\right)$ at 70 DAP \\
Trt 1 & $378.1^{\mathrm{ab}} \pm 10.6$ \\
Trt 2 & $381.9^{\mathrm{a}} \pm 12.7$ \\
Trt 3 & $343.0^{\mathrm{ab}} \pm 8.8$ \\
Trt 4 & $375.2^{\mathrm{ab}} \pm 13.9$ \\
Trt 5 & $364.9^{\mathrm{ab}} \pm 15.2$ \\
Trt 6 & $347.5^{\mathrm{ab}} \pm 10.9$ \\
Trt 7 & $331.1^{\mathrm{ab}} \pm 13.1$ \\
Trt 8 & $283.6^{\mathrm{b}} \pm 6.7$
\end{tabular}

See Table 4 for the definitions of treatments; results are expressed as mean \pm standard deviation of triplicate values of the same sample.

Table 6

Effect of treated rubber effluent on the biomass yield ( $\mathrm{g}$ ) of maize (Z. mays) at 70 DAP.

\begin{tabular}{|c|c|c|c|c|c|c|}
\hline Treatments & Leaves (g) & Roots (g) & Stem (g) & $\operatorname{Cob}(\mathrm{g})$ & Tassel (g) & Total (g) \\
\hline Trt 1 & $6.1^{\mathrm{ab}} \pm 0.5$ & $4.9^{\mathrm{b}} \pm 0.1$ & $14.2^{\mathrm{ab}} \pm 3.2$ & $45.8 \pm 4.6$ & $1.1^{\mathrm{ab}} \pm 0.1$ & 72.1 \\
\hline Trt 2 & $9.8^{\mathrm{a}} \pm 0.4$ & $9.8^{a} \pm 0.6$ & $22.9^{\mathrm{a}} \pm 4.2$ & $46.2 \pm 6.1$ & $1.3^{\mathrm{ab}} \pm 0.1$ & 89.9 \\
\hline Trt 3 & $7.0^{\mathrm{ab}} \pm 2.1$ & $4.3^{\mathrm{b}} \pm 0.1$ & $12.2^{\mathrm{b}} \pm 3.6$ & $39.4 \pm 7.6$ & $1.0^{\mathrm{ab}} \pm 0.1$ & 63.9 \\
\hline Trt 4 & $8.5^{\mathrm{ab}} \pm 2.6$ & $5.7^{\mathrm{a}} \pm 1.1^{\mathrm{b}}$ & $15.9^{\mathrm{ab}} \pm 4.2$ & $46.0 \pm 3.4$ & $1.5^{\mathrm{ab}} \pm 0.1$ & 76.7 \\
\hline Trt 5 & $7.2^{\mathrm{ab}} \pm 0.2$ & $5.7^{\mathrm{ab}} \pm 0.2$ & $14.9^{\mathrm{ab}} \pm 2.4$ & $26.0 \pm 5.1$ & $1.7^{\mathrm{a}} \pm 0.1$ & 55.5 \\
\hline Trt 6 & $7.6^{\mathrm{ab}} \pm 1.2$ & $6.6^{\mathrm{ab}} \pm 1.3$ & $14.2^{\mathrm{ab}} \pm 3.2$ & $43.0 \pm 4.4$ & $1.1^{\mathrm{ab}} \pm 0.1$ & 72.5 \\
\hline Trt 7 & $7.0^{\mathrm{ab}} \pm 0.3$ & $7.1^{\mathrm{ab}} \pm 2.3$ & $15.0^{\mathrm{ab}} \pm 4.1$ & $38.1 \pm 6.5$ & $0.9^{b} \pm 0.1$ & 68.1 \\
\hline Trt 8 & $5.6^{\mathrm{b}} \pm 0.1$ & $6.7^{\mathrm{ab}} \pm 0.4$ & $19.2^{\mathrm{ab}} \pm 3.4$ & $21.3 \pm 6.7$ & $1.5^{\mathrm{a}} \pm 0.1$ & 54.0 \\
\hline
\end{tabular}

See Table 4 for the definitions of treatments; results are expressed as mean \pm standard deviation of triplicate values of the same sample.

was obtained with treatment 2 while the lowest $(72.1 \pm 5.2 \mathrm{~cm})$ was obtained with treatment 1 . At 70 DAP; the maximum plant height of $134.0 \pm 9.2 \mathrm{~cm}$ was obtained with treatment 2 while the lowest of $110.8 \pm 8.6 \mathrm{~cm}$ was obtained with treatment 1 .

The effects of treated rubber effluents on number of leaves of maize plant are also shown in Table 4. At 42 DAP; the highest leaf number of 6 was obtained with treatment 2 while the lowest (5) was obtained with treatment 1. At 49 DAP; the highest number of leaves was 7 with treatment 6 while the lowest of 6 was obtained with treatment 1 . At 56 DAP; the highest number of leaves (9) was obtained with treatment 2 while the lowest (8) was obtained with treatments 1 and 7. At 63 DAP; the highest number of leaves (9) was obtained with treatment 4 while the lowest (9) was obtained with treatment 1 . At 70 DAP; the highest number of leaves (9) was obtained with treatments 4 and 6 while the lowest (9) was obtained in the control plot (treatment 8).

The effects of treated rubber effluent on the stem girth of maize are shown in Table 5. For the different 'Days After Planting' (42, $49,56,63$ and 70 DAPs), the highest values were $4.1 \pm 0.4 \mathrm{~cm}$, $4.9 \pm 0.3 \mathrm{~cm}, 4.7 \pm 0.1 \mathrm{~cm}, 4.5 \pm 0.6 \mathrm{~cm}$ and $4.6 \pm 0.1 \mathrm{~cm}$ respectively obtained with treatment 2 while the lowest values $(3.4 \pm 0.2 \mathrm{~cm}$, $4.4 \pm 0.5 \mathrm{~cm}, 4.0 \pm 0.5 \mathrm{~cm}, 3.9 \pm 0.1 \mathrm{~cm}$ and $3.9 \pm 0.2 \mathrm{~cm}$ respectively) were obtained with treatment 8 . Table 5 also shows the effects of treated rubber effluent on leaf area. The highest average leaf area of $381.9 \pm 12.7 \mathrm{~cm}^{2}$ was obtained with treatment 2 while the lowest value of $283.6 \pm 6.7 \mathrm{~cm}^{2}$ was obtained with treatment 1 .

The effect of treated rubber effluent on the biomass yield of maize is shown in Table 6. The highest leaf weight of $9.8 \pm 0.4 \mathrm{~g}$ was obtained with treatment 2 while the lowest $(5.6 \pm 0.1 \mathrm{~g})$ was
Table 7

Mean chemical composition of the water lettuce plant after wastewater treatment.

\begin{tabular}{lll}
\hline S/N & Components & Values \\
\hline 1 & Crude protein(\%, DM) & $29.00 \pm 1.20$ \\
2 & Total amino acid (\%, DM) & $25.32 \pm 0.82$ \\
3 & Phosphorus(\%,DM) & $2.46 \pm 0.35$ \\
4 & Carbon(\%,DM) & $30.54 \pm 1.33$ \\
5 & Flavonoids(\%, DM) & $3.12 \pm 0.22$ \\
6 & Cellulose (\%,DM) & $12.39 \pm 1.81$ \\
7 & Lignin (\%,DM) & $3.65 \pm 0.76$ \\
8 & Nitrogen (\%,DM) & $4.56 \pm 0.43$ \\
9 & Water content & $92.5 \% \pm 2.35$ \\
\hline
\end{tabular}

Results are expressed as mean \pm standard deviation of triplicate values of the same sample.

obtained with treatment 8 . The highest root weight of $9.8 \pm 0.6 \mathrm{~g}$ was obtained with treatment 2 while the lowest $(4.3 \pm 0.1 \mathrm{~g})$ was obtained with treatment 1 . The highest stem weight of $22.9 \pm 4.2 \mathrm{~g}$ was obtained with treatment 2 while the lowest $(12.2 \pm 3.6 \mathrm{~g})$ was obtained with treatment 3. The highest cob weight of $46.2 \pm 6.1 \mathrm{~g}$ was obtained with treatment 2 while the lowest $(21.3 \pm 6.7 \mathrm{~g})$ was obtained with treatment 8 . The highest tassel weight of $1.7 \pm 0.1 \mathrm{~g}$ was obtained with treatment 5 while the lowest $(1.0 \pm 0.1 \mathrm{~g})$ was obtained with treatment 3 . The chemical composition of the resulting water lettuce plants after treatment is shown Table 7.

\section{Discussion}

Wastewater discharge from the industries under investigation was approximately $1000 \mathrm{~m}^{3} /$ day. The mean physico-chemical and 


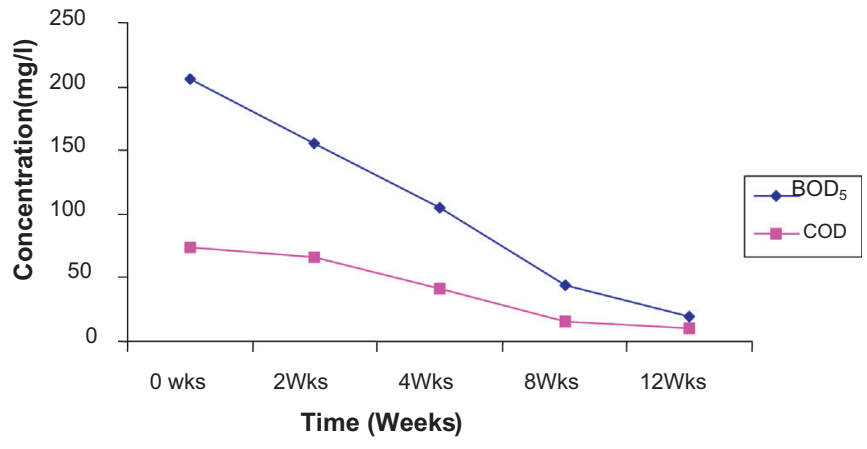

Fig. 1. Plot of $\mathrm{BOD}_{5}$ and $\mathrm{COD}$ with time for 1 st inoculation.

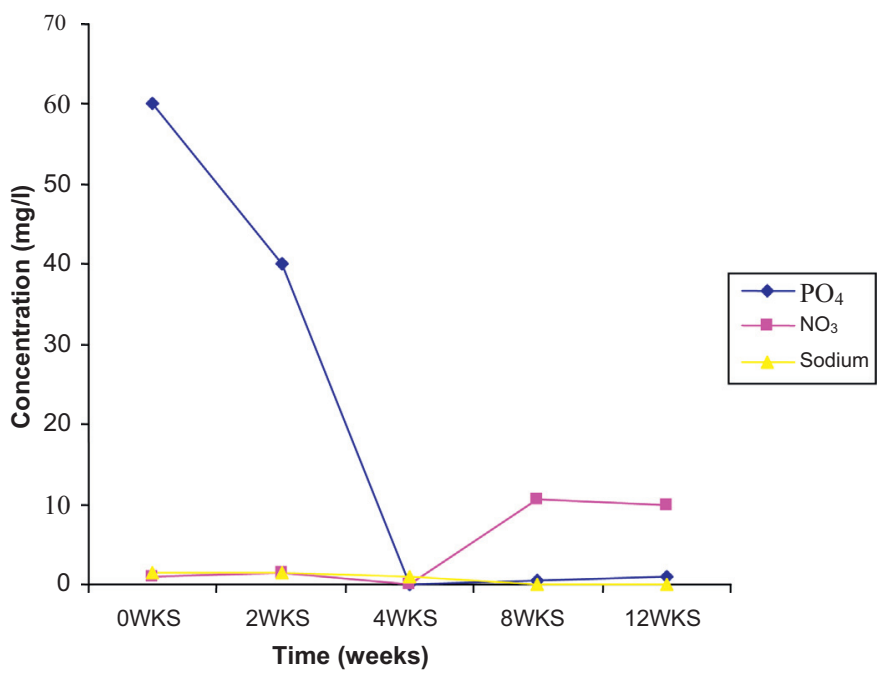

Fig. 2. Plot of $\mathrm{PO}_{4}, \mathrm{NO}_{3}$ and sodium with time for 1 st inoculation.

biological parameters of the untreated composite wastewater sample of Factories A and B (Table 2) when compared with the WHO and FME standards had $\mathrm{pH}, \mathrm{BOD}$, phosphate and TSS values higher than the recommended limits thus; these elements in excess of minimum permissible limits formed the basis for the wastewater monitoring and treatment. Composite samples of Factories A and $B$ were used as influent to the macrophyte pond. The removal efficiency of the water lettuce based macrophyte pond during the entire period of the study is shown in Table 3. The results obtained indicate that biological treatment of the composite wastewater, using water lettuce based macrophyte pond produced effluent with residual COD and BOD values that ranged from $66.0 \pm 8.5 \mathrm{mg} \mathrm{L}^{-1}$ to $10.8 \pm 0.5 \mathrm{mg} \mathrm{L}^{-1}$ and $156.0 \pm 10.9 \mathrm{mg} \mathrm{L}^{-1}$ to $19.5 \pm 3.2 \mathrm{mg} \mathrm{L}^{-1}$ respectively, between the retention period of 2 weeks and 12 weeks during 1st, 2nd and 3rd inoculations. Table 3 also shows that a total coliform removal efficiency of $97.9 \%$ was obtained when retention period was 12 weeks. The maximum BOD, COD and total coliform removal efficiencies of $90.6 \%, 85.5 \%$ and $97.9 \%$ obtained in the 12 th week of treatment is relatively higher than most values recorded in literature for wastewater treatment in ponds using other aquatic weeds (Morari and Giardini, 2009; Fonkou et al., 2002).

Figs. 1-6 show the extent of contaminants (parameters) removal at different retention periods of 2 weeks, 4 weeks, 8 weeks and 12 weeks for the different inoculations thus; reasonable amounts of the organic constituents would have been adsorbed by the water lettuce in the ponds ( $\mathrm{Li}$ et al., 2013). Figs. 1-6 also show that higher efficiencies of pollutants removal occurred mostly at the

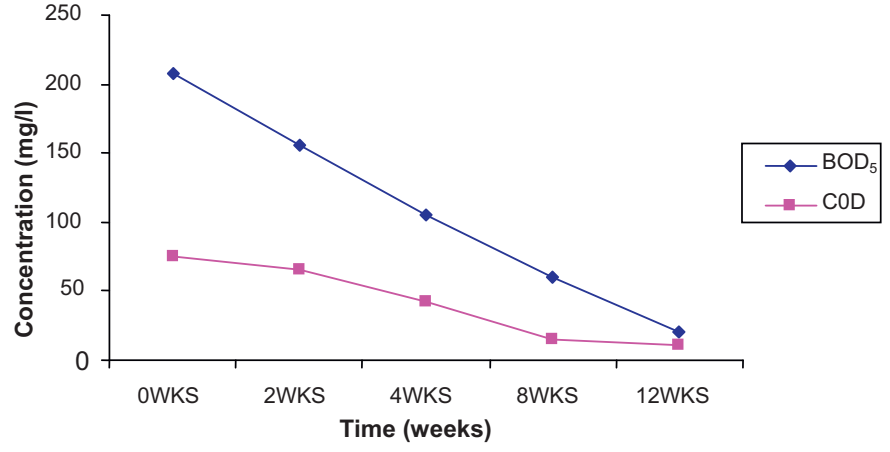

Fig. 3. Plot of $\mathrm{BOD}_{5}$ and $\mathrm{COD}$ with time for 2 nd inoculation.

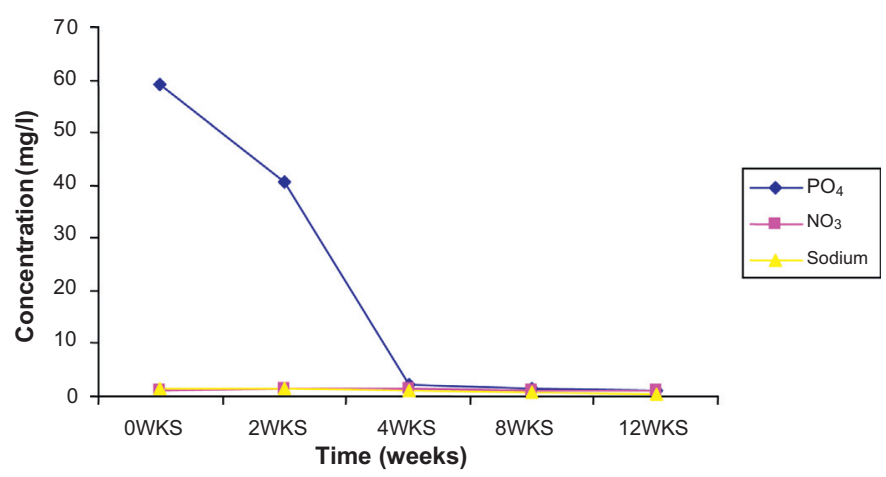

Fig. 4. Plot of $\mathrm{PO}_{4}, \mathrm{NO}_{3}$ and sodium with time after 2 nd inoculation.

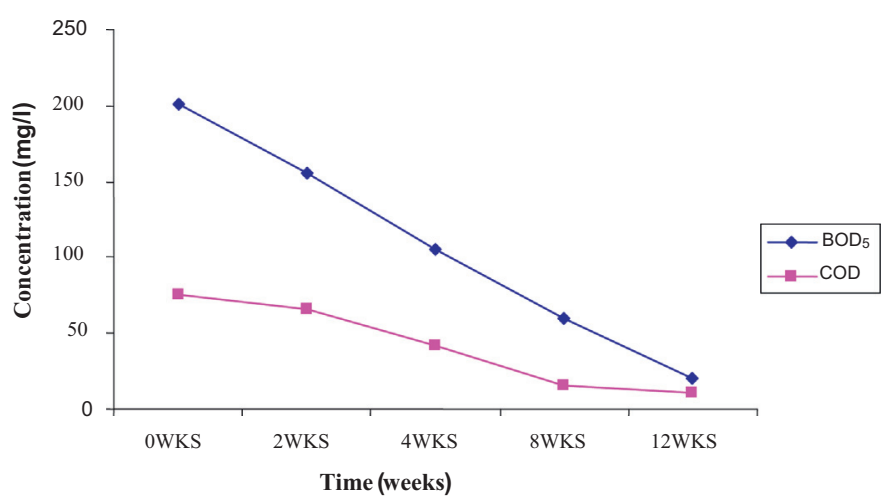

Fig. 5. Plot of $\mathrm{BOD}_{5}$ and $\mathrm{COD}$ with time for 3rd inoculation.

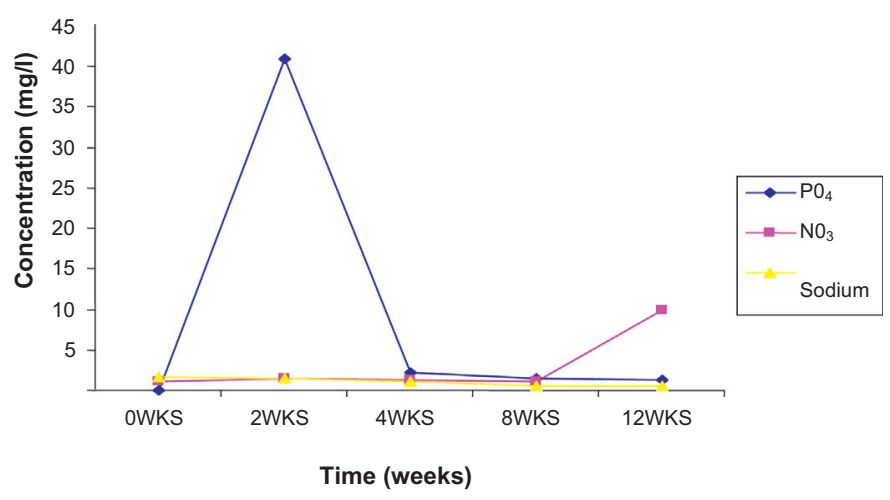

Fig. 6. Plot of $\mathrm{PO}_{4}, \mathrm{NO}_{3}$ and sodium with time for 3rd inoculation. 
12 week retention period for 1 st, 2 nd and 3 rd inoculations. The retention period, however was not extended beyond 12 weeks as the falling of water lettuce leaves into the pond usually increases beyond 12 weeks and would then cause more contamination of the final effluent (Fonkou et al., 2002). This study therefore recommends a retention period of 12 weeks for the design and operation of water lettuce based macrophyte ponds on large scale basis.

Table 4 indicates that there was a significant difference $(P<0.05)$ in the mean plant height at 63 DAP in the treatments. No significant difference between the height of maize plant in treatment 1 when compared with treatment 3 and treatment 8 was observed. This study reveals that treatment 2 produced higher plant height than other treatments (Table 4). This could have resulted from the earlier availability of nutrients to plants by treatment 2 when compared to other treatments. The effect of effluent application on the number of leaves is also presented in Table 4. Though there was no observed significant difference $(P<0.05)$ at 42,56 and 70 DAP, treatment 1 differed significantly from other treatments at 49 and 63 DAP. From Table 5, all treatments considered, generally indicates that rubber effluent to a large extent significantly $(P<0.05)$ increased stem girth. The highest mean stem girth was recorded in treatment 2 followed by treatment 1 . The least mean stem girth was recorded in treatment 8 , which is in agreement with the report of Rajesh and Bhargava (1998) of higher vegetative growth of Triticum aestivum in soils treated with $10 \%$ concentration of sugar mill effluent than in the untreated soil.

Also from Table 5 , there was no significant difference $(P<0.05)$ in the application of effluent on leaf area amongst the treatments except with the control. In line with the report of Karunyal et al. (1993), the highest leaf area in this study was recorded when effluent was applied at time of planting and the lowest recorded in the control where effluent was not applied. The highest biomass yield was recorded in treatment 2 followed by treatment 4 and treatment 5 (Table 6). The lowest biomass yield was recorded in treatment 8 , which is the control. This goes to show that rubber effluent to a large extent increased biomass yield. This is an indication that rubber effluent has nutritive values that could support agricultural production. The use of biofertilizers for agricultural production has in the recent time received great attention as a substitute to chemical fertilizers as biofertilizers help to condition soils and are environment-friendly (Owamah et al., 2014a,b). The average water content of the resulting water lettuce plants was relatively high (92.5\%) when compared with plants that grow on land with water content value of about 70\% (Street and Helgï, 1984). The high value of the nitrogen content of the water lettuce $(4.56 \pm 0.43 \% \mathrm{DM})$ could be attributed to the growing of the plants in a nitrogen rich effluent (Allenby, 1981). The values of the other nutrients analysed for the water lettuce were found within the range of other aquatic plants (Fonkou et al., 2002). These various nutrient content values obtained from the harvested water lettuce plants after the wastewater treatment show that the resulting water lettuce plants after wastewater purification can be used as forage for ruminants (Fonkou et al., 2002), thereby living no room for any significant solid/liquid waste generation from the treatment exercise. The average maximum number of leaves per water lettuce plant was found to be 9 and occurred on the 18th day after the commencement of treatment in the macrophyte pond. Though the authors have tried to establish the possibility and benefits of utilizing water lettuce based ponds for treatment of rubber processing wastewater, they recommend further investigations on the use of water lettuce based ponds on a field scale (and possibly with other wastewater). This further study will help determine the optimum design conditions of the ponds in large scale scenarios.

\section{Conclusion}

This study has shown that water lettuce-based waste stabilization ponds can be used for effective and economical treatment of wastewater from rubber processing industries. The maximum BOD, COD and total coliform removal efficiencies of $90.6 \%, 85.5 \%$ and $97.9 \%$ respectively were obtained in the 12 th week of treatment. The treated effluent obtained in this study was found to have plant nutritive values and can be used as biofertilizer in the production of maize and other annual crops. Though the use of treated effluent as biofertilizer could reduce the farmers' cost of production since effluent is normally discharged freely as waste, end users must be careful and should adhere to international and national safety rules in order to protect public health. The treated effluent liquid was found to greatly increase the growth and yield of the maize plant. The chemical composition of the resulting water lettuce biomass makes it suitable as forage for animal feeding. Biological treatment using water lettuce based ponds is therefore recommended for the treatment of industrial wastewater in developing nations following its low investment cost and the purification efficiency. Biofertilizers are eco-friendly, relatively cheap and could contribute to solving food insecurity problem.

\section{Acknowledgement}

The authors are grateful to Prof. Anyata, B.U of the University of Benin and Prof. Olufayo, A. A of the Federal University of Technology, Akure, all in Nigeria, for their useful comments, supervisions and encouragement made to this study.

\section{References}

Allenby, K.G., 1981. Some analysis of aquatic plants and their water. Hydrobiologica 77, 177-189.

APHA, 1992. Standard Methods for Examination of Water and Waste-Water, 18th Edition. American Public Health Association, Washington DC.

APHA, 2012. Standard Methods for Examination of Water and Waste-water, 22nd Edition. American Public Health Association, Washington DC.

Brisson, J., Chazarenc, F., 2009. Maximizing pollutant removal in constructed wetlands: should we pay more attention to macrophyte species selection? Sci. Tota Environ. 407, 3923-3930.

Fonkou, T., Agendia, P., Kengne, I., Akoa, A., Nya, J., 2002. Potentials of water let tuce (Pistia stratiotes) in domestic sewage treatment with macrophytic lagoon systems in Cameroon. In: Proceedings of International Symposium on Environmental Pollution Control and Waste Management, 7-10 January 2002, Tunis (EPCOWM'2002), pp. 709-714.

Iken, J.E., Amusa, N.A., 2004. Maize research and production in Nigeria. Afr. J. Biotechnol. 3 (6), 302-307.

Jiang, J., 2009. China's water scarcity. J. Environ. Manag. 90, 3185-3196.

Karunyal, S., Renuga, G., Kailash, P., 1993. Effect of tannery effluent on seed germination, leaf area biomass and mineral content of some plants. Bioresour. Technol. 47, 215-218.

Kivaisi, K.A., 2001. The potential for constructed wetlands for wastewater treatment and reuse in developing countries: a review. Ecol. Eng. 16 545-560.

Li, L., Yang, Y., Tam, F.Y.N., Yang, L., Mei, Q.X., Yang, F., 2013. Growth characteristics of six wetland plants and their influences on domestic wastewater treatment efficiency. Ecol. Eng. 60, 382-392.

Masters, G.M., 1991. Introduction to Environmental Engineering and Science. Prentice-Hall, Inc. A Division of Simon \& Schuster Englewood Cliffs, New Jersey, pp. 121.

Morari, F., Giardini, L., 2009. Municipal wastewater treatment with vertical flow constructed wetlands for irrigation. Ecol. Eng. 35, 643-653.

Owamah, I.H., Asiagwu, A.K., Egboh, S.H.O., Phil-Usiayo, S., 2013. Drinking water quality at Isoko North communities of the Niger Delta Region, Nigeria. Toxicol. Environ. Chem., http://dx.doi.org/10.1080/02772248.2013.847939.

Owamah, H.I., Alfa, M.I., Dahunsi, S.O., 2014a. Optimization of biogas from chicken droppings with Cymbopogon citratus. Renew. Energy 68, 366-371.

Owamah, H.I., 2014. Biosorptive removal of $\mathrm{Pb}$ (II) and Cu (II) from wastewater using activated carbon from cassava peels. J Mater. Cycles Waste Manag. 16 347-358.

Owamah, H.I., Dahunsi, S.O., Oranusi, U.S., Alfa, M.I., 2014b. Fertilizer and sanitary quality of digestate biofertilizer from the co-digestion of food waste and human excreta. Waste Manag. 34, 747-752. 
Dahunsi, S.O., Owamah, H.I., Ayandiran, T.A., Oranusi, S.U., 2014. Drinking water quality and public health of selected towns in South Western Nigeria. Water Qual. Expo. Health 6, 143-153.

Papadopoulos, F., Tsihrintzis, A.V., Zdragas, G.A., 2011. Removal of faecal bacteria from septage by treating it in full-scale duckweed-covered pond system. J. Environ. Manag. 92, 3130-3135.

Rajesh, K., Bhargana, A.K., 1998. Effect of sugar mill effluent on the vegetative growth and yield Triticum aestivum cv. U P. Adv. Plant Sci. 11 (2), 221-227.

Snow, A.M., Ghaly, A.E., 2008. A comparative study of the purification of aquaculture wastewater using water hyacinth, water lettuce and parrot's feather. Am. J. Appl. Sci. 5 (4), 440-453.
Stefanakis, A.I., Komilis, D.P., Tsihrintzis, V.A., 2011. Stability and maturity of thickened wastewater sludge treated in pilot-scale sludge treatment wetlands. Water Res. 45 (19), 6441-6524, 6452.

Street, H.E., Helgï, O., 1984. The Physiology of Flowering Plants, 3rd edition. ELBS, Edward Arnold, England, pp. 47.

Uysal, Y., 2013. Removal of chromium ions from wastewater by duckweed, Lemina minorte L. by using a pilot system with continuous flow. J. Hazard. Mater. 263, 486-492.

Wu, R.S.S., 1995. The environmental impact of marine fish culture: towards a sustainable future. Mar. Pollut. Bull. 31, 159-166. 